\title{
The role of insulin-like growth factor system in soft tissue sarcomas: from physiopathology to targeted therapeutic approaches
}

\author{
WALTER ZUMKELLER \\ Department of Hematology/Oncology, Children's University Hospital, Heidelberg, Germany
}

\begin{abstract}
Purpose/Results. Although surgical, chemo- and radiotherapeutic treatment regimens in patients with soft tissue sarcomas have constantly been refined over the past two decades, the survival rate for these patients is rather low.

Discussion. There is a great need to investigate the mechanisms for oncogenesis and to identify the factors involved in malignant transformation in sarcomas. Among these factors, IGFs are thought to play a pivotal role as progression factors in various types of sarcomas. The dysregulation of the IGF-II synthesis, e.g. by loss of imprinting which occurs in most types of sarcomas, is a permissive effect through the suppression of cell death. In addition, cells that overexpress the type I IGF receptors are more susceptible to transformation by oncogenes. As TP53 suppresses the activity of IGF-II P3 and P4, as well as the type I IGF receptor promoter, mutations of TP53 in sarcomas may alternatively lead to the activation of these factors. Finally, the phenomenon of non-islet cell tumour hypoglycaemia that occurs in patients with sarcomas, and which is related to the secretion of IGF-II prohormones, is discussed. Future therapeutic strategies may be based upon the application of antibodies or antisense oligonucleotides directed against the type I IGF receptors, with the common goal of inducing apoptosis in sarcoma cells. Ultimately, these and other therapeutic approaches may lead to a better outcome in patients suffering from sarcoma.
\end{abstract}

Key words: insulin-like growth factors, IGF-binding proteins, soft tissue sarcoma, Ewing's sarcoma, rhabdomyosarcoma, tumour hypoglycaemia.

\section{Introduction}

Steady progress has been made in the identification of genetic alterations and prognostic factors in sarcomas. However, survival rates of patients with sarcomas remain unsatisfactorily low in spite of aggressive treatment involving highly toxic multidrug chemotherapeutic as well as radiotherapeutic regimens. However, considerable progress has been made in the past decade in identifying important factors involved in tumour growth. In addition, the factors involved in the induction and modulation of apoptosis, among them IGFs, are of particular interest. IGF-I and IGF-II are mitogenic polypeptides and are synthesized by most normal and malignant tissues, where they are involved in autocrine and/or paracrine types of action. The IGF system is further complicated by the presence of specific IGF-binding proteins (IGFBP-1 to -7 ) which bind IGFs with high affinity. These IGFBPs are thought to play an important role in modulating IGF responsiveness in normal as well as malignant cells. The biological effects of IGFs are effected through the insulin, type I IGF (IGF-I) and type II (IGF-II) receptors. The type I IGF receptor in particular is involved in growth, differentiation and inhibition of apoptosis depending on activation by IGFs. ${ }^{1}$ Rescue from cell death by IGF-I is mediated through this receptor, and antibodies against this receptor can block the rescuing function of the growth factor. ${ }^{2}$ Moreover, IGF-I had no effect in preventing etoposide-induced apoptosis in fibroblasts derived from mice embryos that have a targeted disruption of the type I IGF receptor. ${ }^{3}$

The autocrine growth hypothesis states that both normal and malignant cells can synthesize and secrete polypeptide growth factors that will bind to their own cell surface receptor and stimulate cell proliferation. ${ }^{4}$ IGFs are abnormally expressed in some paediatric solid tumours, and certain tumours are responsive or dependent upon IGFs for proliferation. In addition, many tumour cell lines express IGFs as autocrine factors and IGFBPs, which, in 
turn, regulate the bioavailability and bioactivity of IGFs. ${ }^{5-7}$ The imprinted genes $I G F-I I$ and $H 19$ are expressed during embryonal life and are downregulated postnatally. $I G F-I I$ is upregulated in paediatric tumours and developmental syndromes predisposing to such tumours (e.g. Beckwith-Wiedemann syndrome). These factors represent tumour markers as they display a tissue-specific oncofetal pattern of expression. ${ }^{8}$ Transgenic mice overexpressing IGF-II have a higher risk of developing tumours, including sarcoma, after a long latent period, which suggests that IGF-II functions primarily as a tumour promoter or progression factor in vivo rather than a potent tumour initiator. ${ }^{9,10}$ Understanding the biology of these growth factors and their receptors can lead to new therapeutic approaches.

\section{Discussion}

The evaluation of 29 human sarcoma specimens revealed high levels of expression for IGF-I, IGF-II and the type I IGF receptor $\mathrm{mRNA}$, as determined by RT-PCR and in comparison with control cell lines. ${ }^{11}$ Analysis of soft tissue sarcoma cells revealed high steady-state levels of the type I IGF receptor mRNA transcripts and protein which correlated with receptor-specific tyrosine kinase activity. ${ }^{12}$ Hypophysectomy profoundly inhibits the metastatic behavior of injected RIF-I fibrosarcoma cells in mice, whereas $\mathrm{GH}$ administration provokes the occurrence of lung metastasis, and it was concluded that somatostatin analogues, GH or IGF antagonists may suppress metastasis of certain tumours. ${ }^{13}$ The presence of IGF-I mRNA in leiomyomas and leiomyosarcomas, ${ }^{14}$ and the IGF-I immunoreactivity in leiomyosarcomas ( 7 out of 8 ), synovial sarcomas (2/3), liposarcomas (3/6), fibrosarcomas (1/3) and in one angiosarcoma, ${ }^{15}$ suggest the potential role for IGF-I in stimulating cell proliferation in these tumours. Contrary to the uniform pattern of IGF-I immunoreactivity seen in other sarcomas, only the spindle cell and not the epithelial component of synovial sarcomas exhibited strong IGF-I immunoreactivity. In malignant fibrous histiocytomas, heterogeneous staining was observed for IGF-I, mostly seen as a diffuse cytoplasmatic reaction in the majority of the tumour cells. A separate study in two noninflammatory fibrous histiocytomas showed also significant immunohistochemical staining for IGF-I. ${ }^{16}$ Abundant IGF-II mRNA species have also been detected in histiocytoma tissue. ${ }^{17}$

\section{Leiomyomas and leiomyosarcomas}

In normal myometrium and leiomyomas, the $I G F$ $I I$ gene is expressed at low levels but it is activated in leiomyosarcomas, whereas the $I G F-I$ gene appears repressed in leiomyosarcomas. ${ }^{18}$ The expression of a fourth leader exon ( $h E 4)$ which leads to the formation of a $5.0-\mathrm{kb}$ mRNA is enhanced 10-fold in leiomyosarcoma tissue, but it has yet to be established whether there is a causal relation between the activation of $h E 4$ expression and tumour formation. ${ }^{19}$ In normal smooth muscle and in leiomyomas the $I G F-I I$ gene appeared to be methylated, whereas, in leiomyosarcomas, methylation of DNA was low and it was suggested that there is an inverse correlation between the methylation state and expression of the $I G F-I I$ gene. $^{20}$ Relaxation of $I G F-I I$ genomic imprinting was also observed in uterine leiomyosarcomata. ${ }^{21}$ There was also a correlation between an $A$ vaII restriction fragment length polymorphism in the $I G F-I I$ gene and the occurrence of smooth muscle tumours. ${ }^{22}$ More than $90 \%$ of liposarcomas exhibit greatly elevated IGF-II mRNA levels, while normal adipose tissue contained very low or undetectable IGF-II levels. ${ }^{23}$

\section{Ewing sarcoma/primitive neuroectodermal tumour}

Most neuroectodermal tumour cell lines and tumours with a $\mathrm{t}(11 ; 22)$ translocation (primitive neuroectodermal tumour (PNET), Ewing's sarcoma, esthesioneuroblastoma) expressed IGF-I mRNA, whereas none of the cell lines without the translocation (PNET, neuroblastoma) expressed IGF-I mRNA transcripts. ${ }^{24,25}$ Data indicate that IGF-I may play an important role for the growth of ES/ PNET tumour cells. ${ }^{26}$ Loss of imprinting (LOI) of $I G F-I I$ occurs in some Ewing's sarcomas but is not associated with increased expression of IGF-II mRNA, suggesting that LOI may be related to genetic or epigenetic abnormalities in tumours independent of $I G F-I I$ expression. ${ }^{27}$

The IGF-I receptor-mediated loop was found to be constantly present in ES/PNET cells and the addition of a specific type I IGF receptor ( $\alpha$ IR-3) antibody suppressed the growth of ES/PNET cells by decreasing the proliferative rate and increasing apoptosis. Furthermore, the $\alpha \mathrm{IR}-3$ antibody significantly inhibited the ability of ES/PNET cells to grow in soft agar and migrate following a chemotactic stimulus. ${ }^{28}$ A decrease in the number of type I IGF receptors causes massive apoptosis in several transplantable tumours, whereas if overexpressed the type I IGF receptor protects cells from apoptosis in vivo. ${ }^{29}$ The IGF-I receptor appears to mediate cellular proliferation and increased transforming ability through its C-terminal domain. ${ }^{30}$ Serum-free growth of Ewing's sarcoma cell lines was achieved by supplementing a basal medium containing IGFI. IGF-I and -II increased DNA synthesis and glucose transport in Ewing's sarcoma cells. ${ }^{31}$ Modulation of the IGF system, which appears to constitute an important stimulator of cell growth in neuroectoderm-derived or -related tumours, can be used to enhance the drug sensitivity of the tumour cells in in vivo and in vitro therapeutic procedures. ${ }^{32}$ 


\section{Desmoplastic small round cell tumour}

Desmoplastic small round cell tumour (DSRCT) is an abdominal malignancy in children characterized by a recurrent chromosomal translocation, $\mathrm{t}(11 ; 22)$ (p13;q12). ${ }^{33,34}$ A genomic DNA fragment containing a Ewing's sarcoma ( $E W S$ ) and a Wilms' tumour (WT1) fusion gene has been isolated from these tumours. ${ }^{35-37}$ The aberrant EWS/WT1 transcription factor activated the type I IGF receptor promoter by approximately $340 \%$, whereas expression vectors encoding either EWS or WT1 reduced the activity of the promoter to 46 and $58 \%$ of control values, respectively. Since the EWS/WT 1 chimeric protein obtains the three C-terminal zinc fingers of the DNA binding domain of WT1, it is possible that this fusion protein may modulate transcription of target genes containing WT1 binding motifs, such as the type 1 IGF receptor gene. Thus, activation of the $I G F-I$ receptor promoter by the EWS/WT1 fusion protein may constitute a potential mechanism for the etiology of this particular malignancy. ${ }^{38}$ In addition, Ewing's sarcoma cells expressing antisense $E W S$ fusion transcripts showed loss of anchorageindependent growth and tumorigenicity in nude mice, which emphasizes the importance of targeting the EWS fusion products as a therapy for the Ewing family of tumours. ${ }^{39}$ Interestingly, in the case of the $E W S / F L I-1$ fusion protein, the IGF-I receptor is required for the transformation of cells. ${ }^{40}$

\section{Rhabdoid tumour of the kidney}

Malignant rhabdoid tumour of the kidney (MRTK) showed strong and specific IGF-II mRNA expression by tumour cells. ${ }^{41,42}$ Clear cell sarcoma of the kidney expresses $I G F-I I$ but not WT1 transcripts, and in situ hybridization patterns for $I G F-I I$ are similar to primitive metanephrogenic blastemal cells and early stromagenic cells. ${ }^{43}$ Slot blot hybridization revealed that IGF-II mRNA was only slightly increased in a clear cell sarcoma of the kidney, but was not elevated in two malignant rhabdoid tumours of the kidney. ${ }^{44}$

\section{Rhabdomyosarcoma}

Recent evidence links abnormal development of the skeletal muscle pathway with rhabdomyosarcoma. The shh/ptc/pax signaling pathway is involved in the induction of myogenic differentiation in somites and in neural tube tissue. A consistant feature of alveolar rhabdomyosarcoma is a translocation involving either a fusion of Pax-3 or, to a lesser extent, Pax-7 with another transcription factor fkhr. ${ }^{45}$ Binding of shh to ptc activates the zinc finger transcription factor gli-1, which is frequently amplified in human sarcomas and brain tumours. ${ }^{46}$ Mice heterozygous for $p t c$ inactivation show a high incidence of rhabdomyosarcoma with overexpression of $p t c, g l i-1$ and
$I G F-I I$ in the tumour, but not in surrounding normal skeletal tissue. This suggests a cross-talk between the ptc and IGF-II signaling pathways in the pathogenesis of rhabdomyosarcoma. ${ }^{47}$

Most rhabdomyosarcomas possess two or more copies of active $I G F-I I$ alleles, arising either by relaxation of imprinting or duplication of the active allele, whereas in normal muscle monoallelic expression of the $I G F-I I$ gene is conserved. ${ }^{48}$ Of the four RMS heterozygotes, $50 \%$ had biallelic expression of $I G F-I I .{ }^{49}$ Furthermore, the imprinting of all $I G F-I I$ promoters is relaxed in RMS, indicating that loss of imprinting of $I G F-I I$ gene promoters may be regulated in a coordinated manner by a common mechanism in these tumours. ${ }^{50}$ In embryonal RMS, a tumour-suppressor locus has been implicated at chromosome band $11 \mathrm{p} 15.5 .^{51}$ Furthermore, there is evidence that this tumour suppressor is imprinted in a manner opposite to that of $I G F-I I .^{52}$ Matsumoto et al. ${ }^{53}$ concluded that loss of imprinting of $I G F-I I$ itself might not induce tumour occurrence in tissues where the control of tissuespecific expression of $I G F-I I$ is maintained, and that increased expression of $I G F-I I$ due to maternal loss of a putative controller gene for IGF-II at $11 \mathrm{p} 15$ might predispose to sustaining tumorigenic mutations and tumour progression, and that loss of a putative onco-suppressor gene at $11 \mathrm{p} 15 \mathrm{might}$ induce RMS occurrence.

$H 19$ is another possible tumour-suppressor gene for embryonal rhabdomyosarcoma as it is also located at chromosome $11 \mathrm{p} 15.5$ and is paternally imprinted. ${ }^{54,55}$ Expression of $H 19$ was observed in four out of six embryonal rhabdomyosarcomas. ${ }^{56}$ The expression of the H19 gene is significantly suppressed as compared to normal muscle tissue in 13 out of 15 rhabdomyosarcomas with embryonal histology, and in three out of 11 rhabdomyosarcomas classified as alveolar subtype. It is evident that the genetic and epigenetic alterations affecting chromosome $11 \mathrm{p} 15$ in a high number of RMSs cause deregulation of several imprinted genes, including the extinction of $H 19$ and an increase in the number of active $I G F-I I$ alleles, thus eventually leading to tumour growth. ${ }^{57}$ On the contrary, cellular growth rates are reduced in $H 19$ transfected embryonal rhabdomyosarcoma cell line. ${ }^{58}$

Rhabdomyosarcoma, a tumour of skeletal muscle origin, appears developmentally arrested at an early stage in the myogenic differentiation pathway. IGFII mRNA has previously been shown to be expressed at high levels in RMS. ${ }^{59,60}$ In the human RMS cell line IN 157, high levels of 6.0-, 4.8- and 4.2-kb IGF-II mRNA transcripts are expressed, whereas normal skeletal muscle expresses negligible amounts of IGF-II mRNA. ${ }^{61}$ In addition, this cell line secretes two forms of IGF-II of medium molecular size, 10 and $7.5 \mathrm{kDa}$, which play a role in the autocrine control of cell growth. ${ }^{62} \mathrm{~A}$ minor $4.8-\mathrm{kb}$ mRNA was exclusively engaged in the synthesis of 
the prepropeptide on membrane-bound polysomes, whereas a major $6.0-\mathrm{kb}$ mRNA was present in a cytoplasmatic particle, suggesting that translational discrimination between the mRNAs is dictated by their different $5^{\prime}$-untranslated regions. ${ }^{63}$ High levels of IGF-II mRNA are found in both alveolar and embryonal RMS. ${ }^{64-66}$ IGF-II mRNA expression is limited to tumour cells and is not found in the surrounding stroma, suggesting that an autocrine loop for IGF-II may be functional in vivo in RMS. ${ }^{65}$ Poorly differentiated RMS showed the highest level of IGF-II mRNA expression, whereas well-differentiated RMS showed low expression, albeit still significantly higher than in normal differentiated skeletal muscle fibers. Thus, IGF-II has potential as a marker for rhabdomyosarcomas and other soft tissue sarcomas that could be especially useful in differential diagnosis of these tumours. ${ }^{67}$ Furthermore, $I G F-I I$ overexpression in myoblasts resulted in an increased proliferative rate, impairment of the ability to differentiate into myoblasts and acquisition of the capability of anchorage-independent growth. It was concluded that $I G F-I I$ overexpression in muscle myoblasts leads to morphological and biological changes typical of the malignant phenotype, and represents a pivotal event in the pathogenesis of RMS. ${ }^{68}$

The capacity of growth factors to induce a motility response in cells has important implications for the invasive and metastatic potential of tumour cells in particular. IGFs, in particular, have the capacity to stimulate cellular motility in tumour cell lines via different receptors and probably different signal transduction pathways. As a consequence, enhanced motility confers upon the cell an increased metastatic potential. ${ }^{7}$ Exogenous IGF-II stimulates cellular motility of rhabdomyosarcoma cell lines via an IGF-I receptor-independent pathway. ${ }^{69}$ IGF-II elicits a mitogenic response through the type I IGF receptor and a motility response through the type II IGF receptor. ${ }^{70}$

Suramin is a polysulfonated naphthyl-urea with antineoplastic activity which interferes non-selectively with the binding of growth factors to their cellular receptors. In particular, it displaces $\left[{ }^{125} \mathrm{I}\right]$ IGF-I from the type I IGF receptor, indicating that suramin exerts its effect on RMS cell growth by interrupting the IGF-II autocrine loop in these cells. ${ }^{71}$ In the alveolar RMZ-RC2 and the embryonal CCA RMS cells, suramin induces a significant increase in the proportion of myosin-positive cells over control cultures. Thus, suramin both inhibits growth and induces myogenic differentiation. ${ }^{72}$

In RD and HTB114 RMS cell lines which express mutant TP53 protein, transfection with wild-type $T P 53$ expression vectors led to a reduction in IGFII P3 promoter expression in these cells. ${ }^{73}$ Furthermore, TP53 binds to the P4 proximal promoter element which results in the inhibition of $\mathrm{P} 4$ activity together with a 5-fold reduction of IGF-II in mRNA derived from the P4 promoter. ${ }^{74}$ In RMS cells, tumour-derived forms of TP53 stimulated the activity of the type I IGF receptor, suggesting that wild-type TP53 has the potential to suppress the type I IGF receptor in the differentiated cell, thus resulting in low levels of receptor gene expression in adult tissues. ${ }^{75}$

Alveolar rhabdomyosarcoma cell lines are very sensitive to the growth-inhibiting effects of the immunosuppressive agent, rapamycin, which inhibits the type I IGF receptor-mediated signalling. ${ }^{76} \mathrm{~A}$ specific type I IGF receptor-blocking antibody $(\alpha \mathrm{IR}$ 3) suppresses RMS growth in vivo. The decrease in tumour growth was associated with a decrease of $p 34^{c d c 2}$, which is involved in cell cycle regulation suggesting that treatment results in the arrest of cellular proliferation. ${ }^{77}$ Transfection of a human alveolar RMS cell line with an amplifiable type I IGF receptor antisense expression vector was associated with markedly reduced growth rates in in vitro, impaired colony formation in soft agar and a failure of tumour formation in immunodeficient mice. ${ }^{78}$ The Rh30 alveolar RMS cells, which are stably transfected with antisense type I IGF receptor, showed significant reduction in growth rate, an increased expression of MyoD, myosin heavy chain, and an increased number of multinucleated cells in comparison to the parental line. The expression of a type I IGF receptor that carries a mutation in the intracellular $\beta$-subunit markedly decreased the response of RMS cells to stimulation with IGF-I and, in addition, resulted in a decrease of RMS growth in vivo suggesting that a prospective gene therapy may use this novel strategy to inhibit RMS growth. ${ }^{79}$ In addition, recombinant human $\alpha_{2 \mathrm{a}}$-interferon induced growth arrest in these cells, associated with down-regulation of the type I IGF receptor. ${ }^{80}$ Overexpression of type I IGF receptors and/or IGF ligands may thus confer a proliferative advantage on sarcomas over normal adjacent tissues. Treatment of both embryonal and alveolar human RMS cell lines with all-trans-retinoic acid resulted in a dosedependent inhibition of cell growth which is not reversed by addition of exogenous IGF-II. $^{81}$ Molecular therapies may also target the signal transduction pathway, in particular the SHC-GRB2 protein complexes and MAP kinases which have been characterized in RMS tumours and cell lines. ${ }^{82}$

Increased circulating levels of IGFBP-2 were found in various neoplastic conditions, including Wilms' tumours ${ }^{83}$ and it was concluded that IGFBP-2 measurements might be of value as a marker for monitoring tumour patients during therapy. Serum IGFBP-2 levels were increased in patients with solid peripheral tumours, whereas patients in complete remission had normal IGFBP2 levels. ${ }^{84}$ In culture, the A 673 RMS cell line has been shown to secrete a specific IGFBP found also in the spinal fluid. ${ }^{85}$ In media conditioned by RMS cell lines A 673 and RD, leiomyosarcoma cell line 
SK-LMS, as well as leiomyoblastoma cell line G 402 , IGFBP-2 has been found in large amounts. ${ }^{86}$ Whereas IGFBP-3 are synthesized at high levels by the leiomyoblastoma cell line $\mathrm{G} 402,{ }^{86}$ levels were decreased in leiomyosarcoma sections ${ }^{87}$ which may confer a growth advantage upon malignant smooth muscle cells.

\section{Non-islet cell tumour hypoglycaemia}

Sarcomas are occasionally associated with the occurrence of hypoglycaemia. Non-islet cell tumours which induce hypoglycaemia are rare. They are usually intra-abdominal or thoracic. The underlying mechanism for the hypoglycaemia is the production of IGF-II, predominantly as a high-molecular weight form ('big' IGF-II), by these tumours. ${ }^{88,89}$ The IGF-II gene is overexpressed in many mesenchymal tumours, and the levels of 'big' IGF-II are increased in serum from patients with non-islet cell tumour hypoglycaemia (NICTH). ${ }^{90}$ In patients with haemangiopericytoma, hypoglycaemia was associated with increased serum levels of 'big' IGF-II. ${ }^{91,92}$ The serum of a patient with a large intra-abdominal haemangiopericytoma contained mainly a largemolecular weight precursor IGF-II (mol. wt. 15$20 \mathrm{kDa}$ ), which disappeared from the serum after operation. ${ }^{93}$ In another patient with a meningeal haemangiopericytoma and a large metastatic liver, hypoglycaemia was associated with low insulin, distinctly decreased IGF-I and normal IGF-II, but high 'big' IGF-II levels. ${ }^{94}$ High levels of IGF-II mRNA and IGF-II peptide were detected in both primary meningeal haemangiopericytoma and metastatic foci in the liver. ${ }^{95}$ In a patient with pelvic clear cell sarcoma, severe hypoglycaemia linked to elevated production of 'big' IGF-II with acromegaloid swelling returned to normal after tumour resection. ${ }^{96}$ A patient with a huge fibrosarcoma in the right liver lobe, associated with hypoglycaemia, became euglycaemic after transcatheter arterial embolization. Interestingly, IGF-II intensely stained in the Golgi area of the tumour cells. ${ }^{97}$ In a leiomyosarcoma, high concentrations of IGF-II mRNA and elevated IGF-II immunoreactivity were detected with a $77 \%$ fraction of high-molecular weight IGF-II ${ }^{98}$ and, in a histiocytoma, a 100-fold elevated IGF-II mRNA level was found as compared to normal liver. ${ }^{99}$ Thus, low or normal IGF-II levels are found in serum, despite demonstrable overexpression of IGF-II mRNA by the tumour. ${ }^{100}$ It was suggested that abnormal IGF-II binding to the $150-k D a$ IGFBP may play a role in tumour-associated hypoglycaemia. ${ }^{101}$ The pro-IGF-II is, to a large extent, bound to low-molecular weight IGFBPs which are able to freely exit the vascular compartment and reach target tissues, where the IGF-II may exert its insulin-like activity. ${ }^{102}$ Serum IGFBP3 was also expressed in forms of about $60 \mathrm{kDa}$ instead of the expected size of about $140 \mathrm{kDa} .^{103}$
Furthermore, not only suppression of IGFBP-3 but also a 10-fold increase of IGFBP-2 levels has been described. ${ }^{104}$

\section{Conclusion}

There is formidable evidence which supports the notion that IGFs play a pivotal role in human cancer. Relaxation of $I G F-I I$ genomic imprinting occurs in childhood as well as adult-onset tumours, and may thus represent a novel epigenetic mechanism for oncogenesis throughout life. The overexpression of the type I IGF receptor renders the cells susceptible to transformation by oncogenes. Thus, attempts are currently being made to inhibit cell proliferation by targeting the IGF-I receptor, by means of anti-receptor antibodies, IGF analogues or antisense strategies, with the common goal of inducing apoptosis of neoplastic cells. ${ }^{105}$ These therapeutic possibilities do offer an intruiging scenario to be developed further in an effort to provide patients affected with different kinds of soft tissue sarcomas with a better outcome.

\section{Acknowledgement}

I wish to express my gratitude to Dr. Paul N. Schofield, Department of Anatomy, University of Cambridge, England, for his kind support and stimulating discussions. The support of the Kinderkrebshilfe Heidelberg is also gratefully acknowledged.

\section{References}

1 Werner H, LeRoith D. The role of the insulin-like growth factor system in human cancer. Adv Cancer Res 1996; 68:183-223.

2 Wu X, Fan Z, Masui H, et al. Apoptosis induced by blocking epidermal growth factor receptors is rescued by insulin through insulin-like growth factor I receptor. Proc Annu Meet Am Assoc Cancer Res 1994; 35:A 16.

3 Sell C, Baserga R, Rubin R. Insulin-like growth factor I (IGF-I) and the IGF-I receptor prevent etoposide-induced apoptosis. Cancer Res 1995; 55:303-6.

4 Sporn MB, Roberts AB. Autocrine growth factors and cancer. Nature 1985; 313:745-7.

5 Zumkeller W, Schofield PN. Growth factors, cytokines and soluble forms of receptor molecules in cancer patients. Anticancer Res 1995; 15:344-8.

6 Zumkeller W, Groth O, Commentz J. Regulation of insulin-like growth factors and IGF-binding proteins in bone tumours. Growth Regul 1996; 6:10-15.

7 Werner H, LeRoith D. The role of the insulin-like growth factor system in human cancer. Adv Cancer Res 1996; 68:183-223.

8 Biran $\mathrm{H}$, Ariel I, de Groot $\mathrm{N}$, et al. Human imprinted genes as oncodevelopmental markers. Tumour Biol 1994; 15:123-34.

9 Rogler CE, Yang D, Rossetti L, et al. Altered body composition and increased frequency of diverse malignancies in insulin-like growth factor-II transgenic mice. F Biol Chem 1994; 269:13779-84. 
10 Bates P, Fisher R, Ward A, et al. Mammary cancer in transgenic mice expressing insulin-like growth factor II (IGF-II). Br $\mathcal{f}$ Cancer 1995; 72:1189-93.

11 Sekyi-Otu A, Bell RS, Ohashi C, et al. Insulin-like growth factor 1 (IGF-1) receptors, IGF-1, and IGF2 are expressed in primary human sarcomas. Cancer Res 1995; 55:129-34.

12 Beech D, Pollock RE, Tsan R, et al. Epidermal growth factor receptor and insulin-like growth factorI receptor expression and function in human soft-tissue sarcoma cells. Int f Oncol 1998; 12:329-36.

13 Sekyi-Otu A, Bell RS, Andrulis IL, et al. Metastatic behaviour of RIF-1 murine fibrosarcoma: inhibited by hypophysectomy and partially restored by growth hormone replacement. I Natl Cancer Inst 1994; 86:628-32.

14 Höppener J, Mosselman S, Roholl PJ, et al. Expression of insulin-like growth factor I and II genes in human smooth muscle tumours. EMBO $\mathcal{f} 1988$; 7:1379-85.

15 Roholl PJ, Skottner A, Prinsen I, et al. Expression of insulin-like growth factor 1 in sarcomas. Histopathology $1990 ; 16: 455-60$.

16 Melhem MF, Meisler AI, Saito R, et al. Cytokines in inflammatory malignant fibrous histiocytoma presenting with leukemoid reaction. Blood 1993; 82:2038-44.

17 Ikejiri K, Wasada T, Haruki K, et al. Identification of a novel transcription unit in the human insulin-like growth factor-II gene. Biochem f 1991; 280:439-44.

18 Gloudemans T, Prinsen I, Van Unnik JAM, et al. Insulin-like growth factor gene expression in human smooth muscle tumours. Cancer Res 1990; 50:6689-95.

19 Holthuizen P, van der Lee FM, Ikejiri K, et al. Identification and initial characterization of a fourth leader exon and promoter of the human IGF-II gene. Biochim Biophys Acta 1990; 1087:341-3.

20 Gloudemans T, Pospiech I, van der Ven LT, et al. Expression and $\mathrm{CpG}$ methylation of the insulin-like growth factor II gene in human smooth muscle tumors. Cancer Res 1992; 52:6516-21.

$21 \mathrm{Vu} \mathrm{TH}$, Yballe C, Boonyanit S, et al. Insulin-like growth factor II in uterine smooth muscle tumors: maintenance of genomic imprinting in leiomyomata and loss of imprinting in leiomyosarcomata. $f$ Clin Endocrinol Metab 1995; 80:1670-6.

22 Gloudemans T, Pospiech I, van der Ven LT, et al. An avaII restriction fragment length polymorphism in the insulin-like growth factor II gene and the occurrence of smooth muscle tumors. Cancer Res 1993; 53:5754-8.

23 Tricoli JV, Rall LB, Karakousis CP, et al. Enhanced levels of insulin-like growth factor messenger RNA in human colon carcinomas and liposarcomas. Cancer Res 1986; 46:6169-73.

24 Yee D, Paik S, Lebovic GS, et al. Analysis of insulinlike growth factor I gene expression in malignancy: evidence for a paracrine role in human breast cancer. Mol Endocrinol 1989; 3:509-17.

25 Yee D, Favoni RE, Lebovic GS, et al. Insulin-like growth factor I expression by tumors of neuroectodermal origin with the $\mathrm{t}(11 ; 22)$ chromosomal translocation. A potential autocrine growth factor. $\mathcal{F}$ Clin Invest 1990; 86:1806-14.

26 Hamilton G, Mallinger R, Hofbauer S, et al. The monoclonal HBA-71 antibody modulates proliferation of thymocytes and Ewing's sarcoma cells by interfering with the action of insulin-like growth factor I. Thymus $1991 ; 18: 33-41$.

27 Zhan S, Shapiro DN, Helman LJ. Loss of imprinting of IGF2 in Ewing's sarcoma. Oncogene 1995; $11: 2503-7$
28 Scotlandi K, Benini S, Sarti $M$, et al. Insulin-like growth factor I receptor-mediated circuit in Ewing's sarcoma/peripheral neuroectodermal tumor: a possible therapeutic target. Cancer Res 1996; 56:4570-4.

29 Resnicoff M, Abraham D, Yutanawiboonchai W, et al. The insulin-like growth factor I receptor protects tumor cells from apoptosis in vivo. Cancer Res 1995; 55:2463-9.

30 Esposito DL, Blakesley VA, Koval AP, et al. Tyrosine residues in the $\mathrm{C}$-terminal domain of the insulin-like growth factor-I receptor mediate mitogenic and tumorigenic signals. Endocrinology 1997; 138:2979-88.

31 van Valen $F$, Winkelmann W, Jürgens $H$. Type I and II insulin-like growth factor receptors and their function in human Ewing's sarcoma cells. $\mathcal{f}$ Cancer Res Clin Oncol 1992; 118:269-75.

32 Hofbauer S, Hamilton G, Theyer G, et al. Insulinlike growth factor-I-dependent growth and in vitro chemosensitivity of Ewing's sarcoma and peripheral primitive neuroectodermal tumour cell lines. Eur $\mathcal{F}$ Cancer 1993; 29A:241-5.

33 Shen WP, Towne B, Zadeh TM. Cytogenetic abnormalities in an intraabdominal desmoplastic small cell tumor. Cancer Genet Cytogenet 1993; 64:189-91.

34 Biegel JA, Conard K, Brooks JJ. Translocation $(11 ; 22)(\mathrm{p} 13 ; \mathrm{q} 12)$ : primary change in intra-abdominal desmoplastic small round cell tumor. Genes Chromosomes Cancer 1993; 7:119-21.

35 Rauscher FJ III, Benjamin LE, Fredericks WJ, et al. Novel oncogenic mutations in the WT1 Wilms' tumor suppressor gene: a $\mathrm{t}(11 ; 22)$ fuses the Ewing's sarcoma gene, EWS 1, to WT1 in desmoplastic small round cell tumor. Cold Spring Harbor Symp Quant Biol 1994; 59:137-46.

36 Ladanyi M, Gerald W. Fusion of the EWS and WT1 genes in the desmoplastic small round cell tumor. Cancer Res 1994; 54:2837-40.

37 Gerald WL, Rosai J, Ladanyi M. Characterization of the genomic breakpoint and chimeric transcripts in the EWS-WT1 gene fusion of desmoplastic small round cell tumor. Proc Natl Acad Sci USA 1995; 92:1028-32.

38 Karnieli E, Werner H, Rauscher FJ 3rd, et al. The IGF-I receptor gene promoter is a molecular target for the Ewing's sarcoma-Wilms' tumor 1 fusion protein. F Biol Chem 1996; 271:19304-9.

39 Ouchida M, Ohno T, Fujimura Y, et al. Loss of tumorigenicity of Ewing's sarcoma cells expressing antisense RNA to EWS-fusion transcripts. Oncogene $1995 ; 11: 1049-54$.

40 Toretsky JA, Kalebic T, Blakesley V, et al. The insulin-like growth factor-I receptor is required for EWS/FLI-1 transformation of fibroblasts. I Biol Chem 1997; 272:30822-7.

41 Gansler T, Gerald W, Anderson G, et al. Characterization of a cell line derived from rhabdoid tumor of the kidney. Hum Pathol 1991; 22:259-66.

42 Sharifah NA, Yun K. Malignant rhabdoid tumor of the kidney expresses insulin-like growth factor II transcripts. Pathology 1994; 26:134-7.

43 Yun K. Clear cell carcinoma of the kidney expresses insulin-like growth factor-II but not WT1 transcripts. Am f Pathol 1993; 142:39-47.

44 Briner J, Hassam S, Rohrer R. Nachweis der unterschiedlichen Expression von IGF-II bei verschiedenen embryonalen Nierentumoren durch slot-blot-Hybridisierung und in-situ-Hybridisierung. Verh Dtsch Ges Pathol 1990; 74:419-23.

45 Zhan S, Helman LJ. Gli the cause of rhabdomyosarcoma. Nature Med 1998; 4:559-60. 
46 Kinzler KW, Vogelstein B. The GLI gene encodes a nuclear protein which binds specific sequences in the human genome. Mol Cell Biol 1990; 10:634-42.

47 Hahn H, Wojnowski L, Zimmer AM, et al. Rhabdomyosarcomas and radiation hypersensitivity in a mouse model of Gorlin syndrome. Nature Med 1998; 4:619-22.

48 Pedone PV, Tirabosco R, Cavazzana AO, et al. Mono- and biallelic expression of insulin-like growth factor II gene in human muscle tumors. Hum $\mathrm{Mol}$ Genet 1994; 3:1117-21.

49 McCann AH, Miller N, O'Meara A, et al. Biallelic expression of the IGF2 gene in human breast disease. Hum Mol Genet 1996; 5:1123-7.

50 Zhan S, Shapiro D, Zhan S, et al. Concordant loss of imprinting of the human insulin-like growth factor II gene promoters in cancer. f Biol Chem 1995; 270:27983-6.

51 Loh WE Jr, Scrable HJ, Livanos E, et al. Human chromosome 11 contains two different growth suppressor genes for embryonal rhabdomyosarcoma. Proc Natl Acad Sci USA 1992; 89:1755-9.

52 Scrable H, Cavenee W, Ghavimi F, et al. A model for embryonal rhabdomyosarcoma tumorigenesis that involves genome imprinting. Proc Natl Acad Sci USA 1989; 86:7480-4.

53 Matsumoto T, Kinoshita E, Maeda H, et al. Molecular analysis of a patient with Beckwith-Wiedemann syndrome, rhabdomyosarcoma and renal cell carcinoma. Jpn f Hum Genet 1994; 39:225-34.

54 Rachmilewitz J, Goshen R, Ariel I, et al. Parental imprinting of the human $\mathrm{H} 19$ gene. FEBS Lett 1992; 309:25-8.

55 Rainier S, Johnson LA, Dobry CJ, et al. Relaxation of imprinted genes in human cancer. Nature 1993; 362:747-9.

56 Ariel I, Ayesh S, Perlman EJ, et al. The product of the imprinted H19 gene is an oncofetal RNA. f Clin Pathol: Mol Pathol 1997; 50:34-44.

57 Casola S, Pedone PV, Cavazzana AO, et al. Expression and parental imprinting of the H19 gene in human rhabdomyosarcoma. Oncogene 1997; 14:1503-10.

58 Hao Y, Crenshaw T, Moulton T, et al. Tumour-suppressor activity of H19 RNA. Nature 1993; 365:764-7.

59 Scott J, Cowell JK, Robertson ME, et al. Insulin-like growth factor-II gene expression in Wilms' tumour and embryonic tissues. Nature 1985; 317:260-2.

60 Gray A, Tam AW, Dull TJ, et al. Tissue-specific and developmentally regulated transcription of the insulin-like growth factor 2 gene. DNA (NY) 1987; 6:283-95.

61 Nielsen FC, Haselbacher G, Christiansen J, et al. Biosynthesis of $10 \mathrm{kDa}$ and $7.5 \mathrm{kDa}$ insulin-like growth factor II in a human rhabdomyosarcoma cell line. Mol Cell Endocrinol 1993; 93:87-95.

62 Gammeltoft S, Christiansen J, Nielsen FC, et al. Insulin-like growth factor II: complexity of biosynthesis and receptor binding. Adv Exp Med Biol 1991; 293:31-44

63 Nielsen FC, Gammeltoft S, Christiansen J. Translational discrimination of mRNAs coding for human insulin-like growth factor II. F Biol Chem 1990; 265:13431-4.

64 Minniti CP, Helman LJ. IGF-II in the pathogenesis of rhabdomyosarcoma: a prototype of IGFs involvement in human tumorigenesis. Adv Exp Med Biol 1993; 343:327-43.

65 Minniti CP, Tsokos M, Newton WA Jr, et al. Specific expression of insulin-like growth factor-II in rhabdomyosarcoma tumor cells. Am f Clin Pathol $1994 ; 101: 198-203$.
66 Zhan S, Shapiro DN, Helman LJ. Activation of an imprinted allele of the insulin-like growth factor II gene implicated in rhabdomyosarcoma. $\mathcal{f}$ Clin Invest 1994; 94:445-8.

67 Yun K. A new marker for rhabdomyosarcoma. Insulin-like growth factor II. Lab Invest 1992; 67:65364.

68 Minniti CP, Luan D, O'Grady C, et al. Insulin-like growth factor II overexpression in myoblasts induces phenotypic changes typical of the malignant phenotype. Cell Growth Diff 1995; 6:263-9.

69 El Badry OM, Minniti C, Kohn EC, et al. Insulinlike growth factor II acts as an autocrine growth and motility factor in human rhabdomyosarcoma tumors. Cell Growth Diff 1990; 1:325-31.

70 Minniti CP, Kohn EC, Grubb JH, et al. The insulinlike growth factor II (IGF/II)/mannose 6-phosphate receptor mediates IGF-II-induced motility in human rhabdomyosarcoma cells. I Biol Chem 1992; 267:9000-4.

71 Minniti CP, Maggi M, Helman LJ. Suramin inhibits the growth of human rhabdomyosarcoma by interrupting the insulin-like growth factor II autocrine growth loop. Cancer Res 1992; 52:1830-5.

72 De Giovanni C, Melani C, Nanni P, et al. Redundancy of autocrine loops in human rhabdomyosarcoma cells: induction of differentiation by suramin. Br f Cancer 1995; 72:1224-9.

73 Zhang L, Kashanchi F, Zhan Q, et al. Regulation of insulin-like growth factor II P3 promotor by p53: a potential mechanism for tumorigenesis. Cancer Res 1996; 56:1367-73.

74 Zhang L, Zhan Q, Zhan S, et al. p53 regulates human insulin-like growth factor II gene expression through active $\mathrm{P} 4$ promoter in rhabdomyosarcoma cells. DNA Cell Biol 1998; 17:125-31.

75 Werner H, Karnieli E, Rauscher FJ, et al. Wild-type and mutant p53 differentially regulate transcription of the insulin-like growth factor I receptor gene. Proc Natl Acad Sci USA 1996; 93:8318-23.

76 Dilling MB, Dias P, Shapiro DN, et al. Rapamycin selectively inhibits the growth of childhood rhabdomyosarcoma cells through inhibition of signaling via the type I insulin-like growth factor receptor. Cancer Res 1994; 54:903-7.

77 Kalebic T, Tsokos M, Helman LJ. In vivo treatment with antibody against IGF-I receptor suppresses growth of human rhabdomyosarcoma and down-regulates p34 ${ }^{\text {cdc2 }}$. Cancer Res 1994; 54:5531-4.

78 Shapiro DN, Jones BG, Shapiro LH, et al. Antisense-mediated reduction in insulin-like growth factor-I receptor expression suppresses the malignant phenotype of a human alveolar rhabdomyosarcoma. f Clin Invest 1994; 94:1235-42.

79 Kalebic T, Blakesley V, Slade C, et al. Expression of a kinase-deficient IGF-I-R suppresses tumorigenicity of rhabdomyosarcoma cells constitutively expressing a wild type IGF-I-R. Int f Cancer 1998; $76: 223-7$

80 Thulasi R, Dias P, Houghton PJ, et al. Alpha 2a-interferon-induced differentiation of human alveolar rhabdomyosarcoma cells: correlation with downregulation of the insulin-like growth factor type I receptor. Cell Growth Diff 1996; 7:531-41.

81 Crouch GD, Helman LJ. All-trans-retinoic acid inhibits the growth of human rhabdomyosarcoma cell lines. Cancer Res 1991; 51:4882-7.

82 McManus MJ, Hutt PJ, Maihle NJ. Phosphotyrosyl proteins in childhood rhabdomyosarcomas: phosphorylation of catenins and components of the insulin-like growth factor type I receptor signalling cascade. F Pediatr Hematol Oncol 1997; 19:319-26. 
83 Zumkeller W, Schwander J, Mitchell CD, et al. Insulin-like growth factor (IGF)-I, -II and IGF binding protein-2 (IGFBP-2) in the plasma of children with Wilms' tumour. Eur f Cancer 1993; 29A:19737 .

84 Müller HL, Oh Y, Lehrnbecher T, et al. Insulin-like growth factor binding protein-2 concentrations in cerebrospinal fluid and serum of children with malignant solid tumors or acute leukemia. f Clin Endocrinol Metab 1994; 79:428-34.

85 Romanus JA, Tseng LY, Yang YW, et al. The 34 kilodalton insulin-like growth factor binding proteins in human cerebrospinal fluid and the A673 rhabdomyosarcoma cell line are human homologues of the rat BRL-3A binding protein. Biochem Biophys Res Commun 1989; 163:875-81.

86 Koscielniak EB, Gutbrod R, Blum W, et al. Varying patterns of secretion of insulin-like growth factors (IGFs) and their binding proteins (BPs) by sarcoma cell lines. Proc Am Assoc Cancer Res. 1994; 35:44.

87 van der Ven LT, van Buul-Offers SC, Gloudemans $\mathrm{T}$, et al. Modulation of insulin-like growth factor (IGF) action by IGF-binding proteins in normal, benign, and malignant smooth muscle tissues. $\mathcal{f} \mathrm{Clin}$ Endocrinol Metab 1996; 81:3629-35.

88 Lowe WL Jr, Roberts CT Jr, LeRoith D, et al. Insulin-like growth factor-II in nonislet cell tumors associated with hypoglycemia: increased levels of messenger ribonucleic acid. $\mathcal{F}$ Clin Endocrinol Metab 1989; 69:1153-9.

89 Schofield PN, Nyström A, Smith J, et al. Expression of a high molecular weight form of insulin-like growth factor II in a Beckwith-Wiedemann syndrome associated adrenocortical adenoma. Cancer Lett 1995; 94:71-7.

90 Daughaday WH, Trivedi B, Baxter RC. Serum 'big insulin-like growth factor II' from patients with tumor hypoglycemia lacks normal E-domain O-linked glycosylation, a possible determinant of normal propeptide processing. Proc Natl Acad Sci USA 1993; 90:5823-7.

91 Daughaday WH, Emanuele MA, Brooks MH, et al. Synthesis and secretion of insulin-like growth factor II by a leiomyosarcoma with associated hypoglycemia. N Engl f Med 1988; 319:1434-40.

92 Chung J, Henry RR. Mechanisms of tumor-induced hypoglycemia with intraabdominal hemangiopericytoma. F Clin Endocrinol Metab 1996; 81:919-25.

93 Höög A, Sandberg-Nordqvist AC, Hulting AL, et al. High molecular weight IGF-2 expression in a haemangiopericytoma associated with hypoglycemia. APMIS 1997; 105:469-82.
94 Cotterill AM, Holly JM, Davies SC, et al. The insulin-like growth factors and their binding proteins in a case of non-islet-cell tumour-associated hypoglycaemia. J Endocrinol 1991; 131:303-11.

95 Wegmann W, Vonesch HJ, Kamber J, et al. Rezidivierendes und metastasierendes Hämangioperizytom der Meningen mit paraneoplastischer Hypoglykämie. Schweiz Med Wochenschr 1994; 124:146-51.

96 Sohda T, Yun K. Insulin-like growth factor II expression in primary meningeal hemangiopericytoma and its metastasis to the liver accompanied by hypoglycemia. Hum Pathol 1996; $27: 858-61$.

97 Trivedi N, Mithal A, Sharma AK, et al. Non-islet cell tumour induced hypoglycemia with acromegaloid facial and acral swelling. Clin Endocrinol 1995; 42:433-5.

98 Kotani K, Tsuji M, Oki A, et al. IGF-II producing hepatic fibrosarcoma associated with hypoglycemia. Intern Med 1993; 32:897-901.

99 Wasada $\mathrm{T}$, Hizuka $\mathrm{N}$, Yamamoto $\mathrm{M}$, et al. An insulin-like growth factor II-producing histiocytoma associated with hypoglycemia: analysis of the peptide, its gene expression, and glucose transporter isoforms. Metabolism 1992; $41: 310-6$

100 Schofield PN, Connor H, Turner RC, et al. Tumour hypoglycaemia: raised tumour IGFII mRNA associated with reduced plasma somatomedin. Br $\mathcal{f}$ Cancer 1989; 60:661-3.

101 Daughaday WH, Kapadia M. Significance of abnormal serum binding of insulin-like growth factor II in the development of hypoglycemia in patients with non-islet-cell tumors. Proc Natl Acad Sci USA 1989; 86:6778-82.

102 Baxter RC. The role of insulin-like growth factors and their binding proteins in tumor hypoglycemia. Horm Res 1996; 46:195-201.

103 Baxter RC, Daughaday WH. Impaired formation of the ternary insulin-like growth factor-binding protein complex in patients with hypoglycemia due to nonislet cell tumors. F Clin Endocrinol Metab 1991; 73:696-702.

104 Baxter RC, Holman SR, Corbould A, et al. Regulation of the insulin-like growth factors and their binding proteins by glucocorticoid and growth hormone in nonislet cell tumor hypoglycemia. $\mathcal{F}$ Clin Endocrinol Metab 1995; $80: 2700-8$

105 Baserga R. The insulin-like growth factor I receptor: a key to tumor growth? Cancer Res 1995; 55:249-52. 


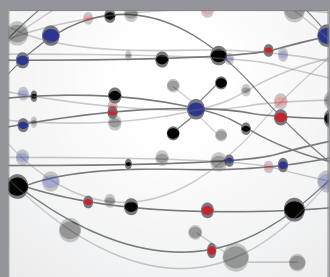

The Scientific World Journal
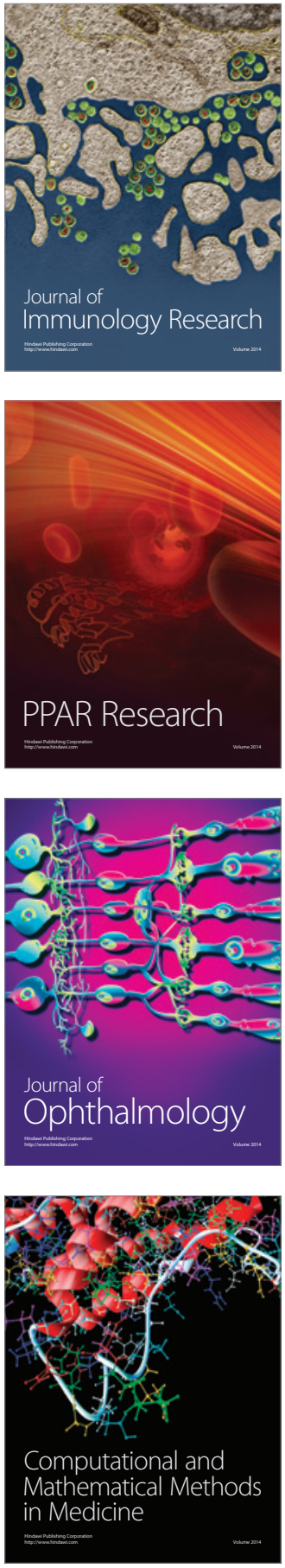

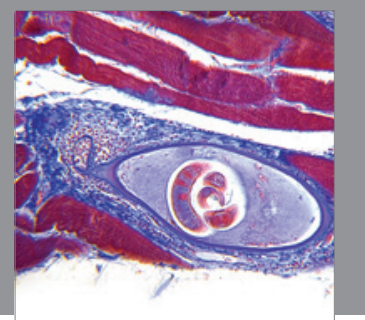

Gastroenterology

Research and Practice
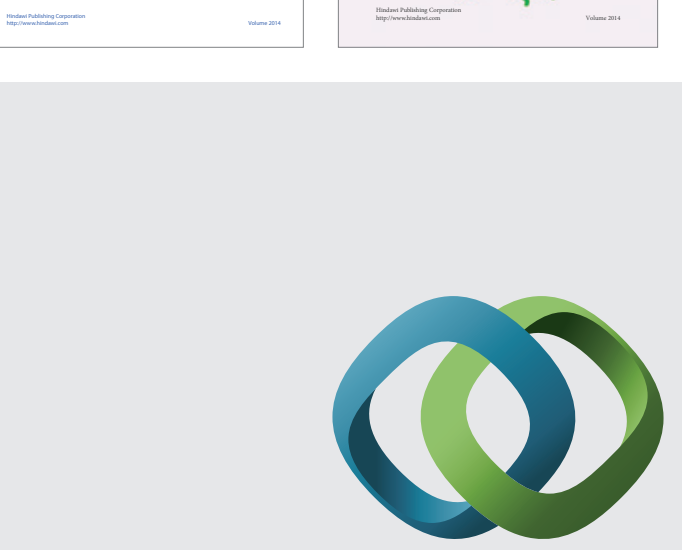

\section{Hindawi}

Submit your manuscripts at

http://www.hindawi.com
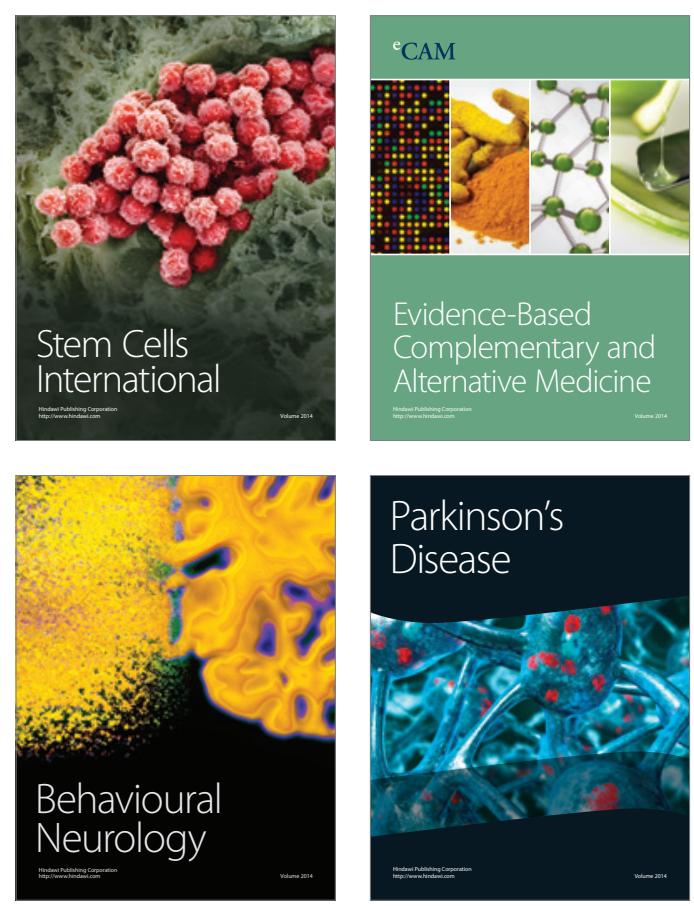

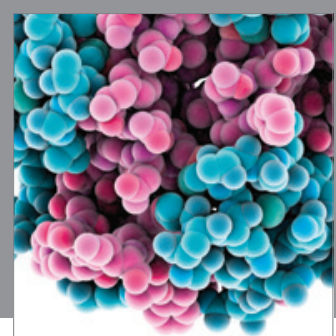

Journal of
Diabetes Research

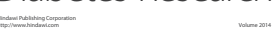

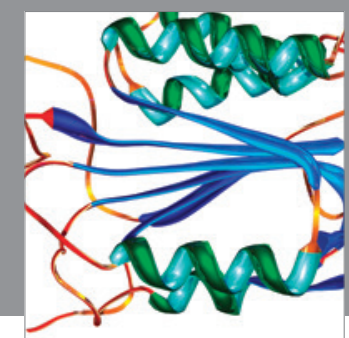

Disease Markers
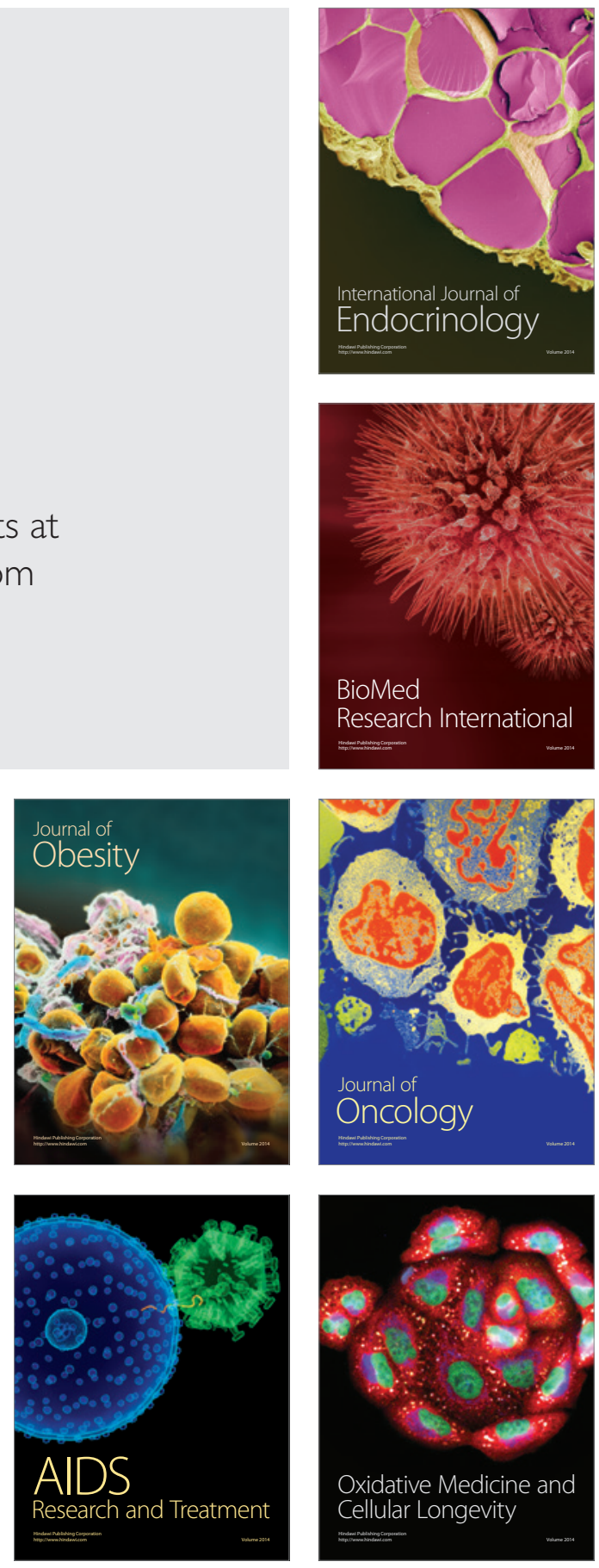